\title{
Anterior transpericardial approach for postchemotherapy residual midvisceral mediastinal mass in metastatic germ cell tumors
}

\author{
Marc de Perrot, MD, ${ }^{\mathrm{a}}$ Donna Eaton, MD, ${ }^{\mathrm{a}}$ Philippe L. Bedard, MD,${ }^{\mathrm{b}}$ and Michael Jewett, MD, ${ }^{\mathrm{c}}$ Toronto, \\ Ontario, Canada
}

Resection of residual mediastinal and pulmonary masses after chemotherapy for metastatic nonseminomatous germ cell tumors (NSGCTs) of the testis is indicated to eradicate potential residual teratomas or malignant tumors. Kesler ${ }^{1}$ elegantly described the pattern of mediastinal dissemination from NSGCT of the testis into the upper, mid-, and lower visceral mediastinum, along with potential involvement of the anterior mediastinum, paravertebral sulcus, or pulmonary hilum. The midvisceral mediastinum is located in the retrocardiac mediastinal space along the thoracic duct between the azygos vein and the descending aorta. This area is a frequent site of mediastinal involvement in patients with metastatic testicular NSGCT and is typically approached through a right posterolateral thoracotomy. ${ }^{1-3}$ However, a transpericardial approach to the midvisceral mediastinum is an important option to consider when an anterior approach is required for other sites of mediastinal disease. We present our experience with the anterior transpericardial approach.

\section{CLINICAL SUMMARY}

After approval by the institutional review board of Toronto General Hospital and Princess Margaret Hospital and informed consent was waived, a retrospective review of a prospective database identified 46 consecutive patients undergoing thoracic surgery for metastatic NSGCT of the testis at Toronto General Hospital and Princess Margaret Hospital between January 2005 and March 2012. Eleven patients presented with disease located in the midvisceral mediastinum. In 4 patients, the midvisceral mediastinum was approached through a right posterolateral thoracotomy because of the absence of other site of mediastinal disease $(n=1)$, the presence of disease along the right paravertebral sulcus in association with the

From the Division of Thoracic Surgery, ${ }^{a}$ Division of Medical Oncology and Hematology, ${ }^{\mathrm{b}}$ and Division of Urology, ${ }^{\mathrm{c}}$ Toronto General Hospital and Princess Margaret Hospital, University Health Network, Toronto, Ontario, Canada.

Disclosures: Authors have nothing to disclose with regard to commercial support.

Received for publication Sept 10, 2012; revisions received Nov 4, 2012; accepted for publication Dec 5, 2012; available ahead of print Jan 10, 2013.

Address for reprints: Marc de Perrot, MD, MSc, Division of Thoracic Surgery, 200 Elizabeth St, Toronto General Hospital, 9N-961, Toronto, Ontario M5G 2C4,

Canada (E-mail: marc.deperrot@uhn.on.ca).

J Thorac Cardiovasc Surg 2013;145:1136-8

0022-5223/ $\$ 36.00$

Copyright (c) 2013 by The American Association for Thoracic Surgery

http://dx.doi.org/10.1016/j.jtcvs.2012.12.009 mid-visceral mediastinum $(\mathrm{n}=1)$, the extent of disease in the pulmonary hilum $(\mathrm{n}=1)$, or salvage surgery $(\mathrm{n}=1)$. The remaining 7 patients underwent an anterior transpericardial approach to the midvisceral mediastinum along with resection of other sites of disease located in the upper visceral mediastinum $(n=4)$, lower visceral mediastinum $(\mathrm{n}=4)$, anterior mediastinum $(\mathrm{n}=3)$, pulmonary hilum $(\mathrm{n}=2)$, and lung parenchyma $(\mathrm{n}=3)$ (Table 1). All 7 patients received first-line cisplatin-based chemotherapy and presented to surgery with normalized serum tumor markers.

Patients were positioned supine. A sternotomy was performed in 6 patients, and a clamshell incision was performed in 1 patient because of extensive lung disease requiring an anatomic segmentectomy of the left upper lobe. After sternotomy or clamshell incision, the anterior and upper visceral mediastinal sites of disease were resected first to expose the superior vena cava, carina, aortic arch, and pulmonary artery. The anterior pericardium was opened between the ascending aorta and the diaphragm. The ascending aorta was then dissected circumferentially to expose the main pulmonary artery. The posterior pericardium was opened, and the right pulmonary artery was dissected from its bifurcation to the right hilum. Complete mobilization of the right main pulmonary artery exposed the subcarinal space (Figure 1). The subcarinal space was then dissected, and the posterior pericardium retracted anteriorly to access the midvisceral mediastinum where the tumor could be dissected off the azygos vein, esophagus, posterior pericardium, and aorta. The thoracic duct was clipped at the upper and lower ends of the tumor. Manual palpation of the tumor through the right pleural space was occasionally helpful to facilitate the retrocardiac dissection.

In 5 patients, the transsternal transpericardial approach was combined with a midline laparotomy, retroperitoneal lymph node dissection, or transdiaphragmatic resection of retrocrural disease. All but 1 patient had complete resection of the thoracic disease through the anterior approach. One patient required an additional left posterolateral thoracotomy to remove residual disease located in the left paravertebral sulcus. Pathologic examination of the mediastinal masses demonstrated mature teratomas $(\mathrm{n}=5)$, nonnecrotizing granulomatous lymphadenitis $(\mathrm{n}=1)$, and necrosis $(\mathrm{n}=1)$. Pneumonitis developed postoperatively in 2 patients, but they fully recovered and were discharged. 
TABLE 1. Patient characteristics

\begin{tabular}{|c|c|c|c|c|c|c|c|c|c|c|}
\hline Patient & $\begin{array}{c}\text { Location of } \\
\text { thoracic } \\
\text { disease } \\
\end{array}$ & Incision & $\begin{array}{l}\text { Midvisceral } \\
\text { mediastinal } \\
\text { tumor size* }\end{array}$ & $\begin{array}{c}\text { Combined } \\
\text { RPLND } \dagger \\
\end{array}$ & $\begin{array}{c}\text { Duration of } \\
\text { surgery }\end{array}$ & $\begin{array}{c}\text { Blood } \\
\text { loss }(\mathrm{mL})\end{array}$ & Complications & $\begin{array}{c}\text { Hospital } \\
\text { stay (d) }\end{array}$ & $\begin{array}{c}\text { Additional } \\
\text { thoracic } \\
\text { surgery } \\
\end{array}$ & Follow-up (mo) \\
\hline 1 & $\begin{array}{l}\text { Anterior } \\
\text { mediastinum, } \\
\text { midvisceral } \\
\text { mediastinum, } \\
\text { retrocrural, } \\
\text { lung }\end{array}$ & Sternolaparotomy & $4 \mathrm{~cm}$ & Yes & $870 \mathrm{~min}$ & 4500 & Pneumonitis & 24 & No & $\begin{array}{l}\text { Alive without } \\
\text { recurrence (15) }\end{array}$ \\
\hline 2 & $\begin{array}{l}\text { Midvisceral } \\
\text { mediastinum, } \\
\text { retrocrural, } \\
\text { lung }\end{array}$ & Sternolaparotomy & $2.1 \mathrm{~cm}$ & Yes & $570 \mathrm{~min}$ & 3000 & No & 9 & Yes $\dagger$ & $\begin{array}{l}\text { Alive without } \\
\text { recurrence (26) }\end{array}$ \\
\hline 3 & $\begin{array}{l}\text { Anterior } \\
\text { mediastinum, } \\
\text { paratracheal, } \\
\text { hilar, } \\
\text { midvisceral } \\
\text { mediastinum, } \\
\text { lung }\end{array}$ & Clamshell & $2.4 \mathrm{~cm}$ & No & $360 \mathrm{~min}$ & 1000 & No & 9 & No & $\begin{array}{l}\text { Lung and brain } \\
\text { recurrence (11) }\end{array}$ \\
\hline 4 & $\begin{array}{l}\text { Midvisceral } \\
\text { mediastinum, } \\
\text { retrocrural }\end{array}$ & Sternolaparotomy & $2.8 \mathrm{~cm}$ & Yes & $330 \mathrm{~min}$ & 800 & No & 7 & No & $\begin{array}{l}\text { Alive without } \\
\text { recurrence (78) }\end{array}$ \\
\hline 5 & $\begin{array}{l}\text { Anterior } \\
\text { mediastinal, } \\
\text { paratracheal, } \\
\text { midvisceral } \\
\text { mediastinum }\end{array}$ & Sternotomy & $3 \mathrm{~cm}$ & No & $240 \mathrm{~min}$ & 500 & No & 5 & No & $\begin{array}{l}\text { Alive without } \\
\text { recurrence (29) }\end{array}$ \\
\hline 6 & $\begin{array}{l}\text { Paratracheal, } \\
\text { retrocrural, } \\
\text { midvisceral } \\
\text { mediastinum }\end{array}$ & Sternolaparotomy & $2.5 \mathrm{~cm}$ & Yes & $510 \mathrm{~min}$ & 3300 & Pneumonitis & 16 & No & $\begin{array}{l}\text { Alive without } \\
\quad \text { recurrence (41) }\end{array}$ \\
\hline 7 & $\begin{array}{l}\text { Paratracheal, } \\
\text { hilar, } \\
\text { midvisceral } \\
\text { mediastinum }\end{array}$ & Sternolaparotomy & $3.8 \mathrm{~cm}$ & Yes & $570 \mathrm{~min}$ & 1000 & No & 13 & No & $\begin{array}{l}\text { Alive without } \\
\text { recurrence (7) }\end{array}$ \\
\hline
\end{tabular}

Hospital length of stay ranged between 5 and 24 days (median, 9 days). After a median follow-up of 26 months (7-78 months), all but 1 patient are alive with no evidence of recurrence. Lung and brain metastases developed during follow-up in 1 patient.

\section{DISCUSSION}

Median sternotomy is often the most versatile approach for patients with multiple sites of residual mediastinal disease after chemotherapy for metastatic testicular NSGCT because it provides exposure to the upper visceral mediastinum, anterior mediastinum, both lungs, and pulmonary hilum. This approach can also be combined with a midline laparotomy to perform the retroperitoneal and retrocrural lymph node dissection during the same procedure. ${ }^{4}$
The anterior transpericardial approach to access the midvisceral mediastinum is therefore particularly beneficial in patients with multiple sites of mediastinal disease to be able to remove all residual diseases in 1 procedure and avoid the need for an additional right thoracotomy or thoracoscopic approach.

\section{CONCLUSIONS}

The anterior transpericardial approach provides adequate exposure to resect residual metastatic NSGCTs up to $4 \mathrm{~cm}$ in axial diameter that are located in the midvisceral mediastinum and extend down to the right inferior pulmonary vein. In addition to providing access to the carina, subcarinal space, and retropericardial collection, the transsternal transpericardial approach should be considered for resection of 

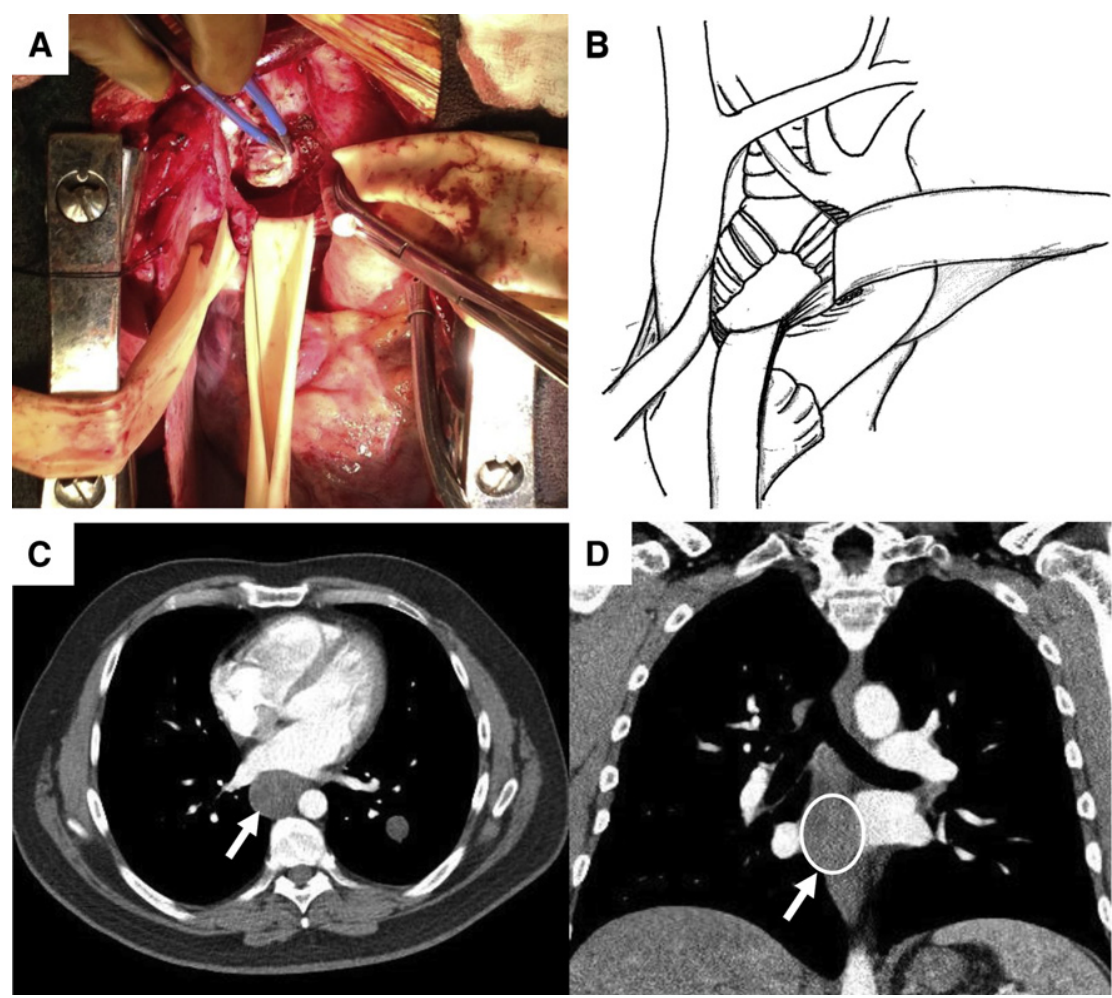

FIGURE 1. Intraoperative view (A) and drawing (B) of the anterior transpericardial approach to the midvisceral mediastinum. After opening the anterior and posterior pericardia, the ascending aorta, superior vena cava, and right main pulmonary artery are dissected and encircled. Complete mobilization of the right main pulmonary artery and ascending aorta exposes the subcarinal space. Dissection of the subcarinal space then provides access to the midvisceral mediastinum down to the inferior pulmonary veins. Axial (C) and coronal (D) views of computed tomography scans from the same patient demonstrate the location of the residual metastatic NSGCT in the midvisceral mediastinum (white arrow and circle) accessible through an anterior transpericardial approach. These tumors are typically located caudally and posteriorly to the subcarinal space.

tumors and cysts located in the retrocardiac mediastinal space. $^{5}$

\section{References}

1. Kesler KA. Surgical technique for testicular nonseminomatous germ cell tumors metastatic to the mediastinum. Chest Surg Clin N Am. 2002;12: 749-68.

2. Kesler KA, Brooks JA, Rieger KM, Fineberg NS, Einhorn LH, Brown JW. Mediastinal metastases from testicular nonseminomatous germ cell tumors: patterns of dissemination and predictors of long-term survival with surgery. $J$ Thorac Cardiovasc Surg. 2003;125:913-23.

3. Brenner PC, Herr HW, Morse MJ, Sheinfeld J, Aprikian A, Bosl GJ, et al. Simultaneous retroperitoneal, thoracic, and cervical resection of postchemotherapy residual masses in patients with metastatic nonseminomatous germ cell tumors of the testis. J Clin Oncol. 1996;14:1765-9.

4. Fadel E, Court B, Chapelier AR, Droz JP, Dartevelle P. One-stage approach for retroperioteneal and mediastinal metastatic testicular tumor resection. Ann Thorac Surg. 2000;69:1717-21.

5. Stella F, Petrella F. Transsternal transpericardial approach for acute descending necrotizing mediastinitis. J Thorac Cardiovasc Surg. 2005;129:212-4. 